\title{
Comparison of the in situ technique and the gas production technique in mimicking rumen dry matter degradation
}

\author{
J.M.J. Gosselink ${ }^{1,2,3}$, J.P. Dulphy ${ }^{1}$, S. Tamminga ${ }^{2}$ and J.W. Cone \\ ${ }^{1} I N R A$, Centre de Clermont-Ferrand-Theix, Unité de Recherches sur les Herbivores \\ 63122 Saint-Genès Champanelle, France \\ ${ }^{2}$ Wageningen Institute of Animal Sciences \\ P.O. Box 338, NL-6700 AH Wageningen, The Netherlands \\ ${ }^{3}$ Animal Sciences Group of Wageningen UR, Nutrition and Food \\ P.O. Box 65, NL-8200 AB Lelystad, The Netherlands
}

\begin{abstract}
The objective of this study was to compare the dry matter degradability of forages as determined with the in situ nylon bag technique and the gas production technique. The effective degradable DM measured with the in situ technique (situ DDM) was well related with the gas production after $20 \mathrm{~h}$, when situ DDM was calculated with a passage rate equal to the degradation rate. The degradation rate obtained with the in situ technique was moderately related with the time at which $50 \%$ of the maximal gas production was reached in the second phase of the gas production technique.
\end{abstract}

KEY WORDS: nylon bag, gas production, dynamic, degradation, organic matter

\section{INTRODUCTION}

In the past 40 years great efforts were done to develop techniques to mimic rumen fermentation, as in vivo measurements are expensive and laborious and reduce animal welfare. Using these techniques, the rumen degradation of $\mathrm{OM}$ (DOM) can be predicted. DOM is a good measure for energy production in the rumen and an important factor for determining the potential synthesis of microbial protein in the rumen (Vérité et al., 1987; Tamminga et al., 1994).

The most frequently used alternative techniques are the in situ technique and the gas production technique. Comparisons of these techniques in measuring rumen degradation of feed and other parameters of rumen fermentation are

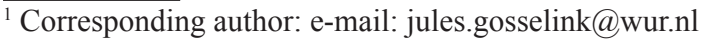


scarce. Rymer and Givens (2002) studied relationships between patterns of rumen fermentation, the in situ degradability and gas production profiles.

In this study the results of dry matter degradation of forages were compared for the in situ technique (Michalet-Doreau et al., 1987) and the gas production technique (Cone et al., 1996).

\section{MATERIAL AND METHODS}

\section{Forages}

Twelve forages, used in this study, were investigated in the fresh form, as silage or hay. The forages were lucerne (Medicago sativa), red clover (Trifolium pratense), orchard grass (Dactylis glomerata) and perennial ryegrass (Lolium perenne). Red clover haylage, a wilted forage wrapped in bales and with a dry matter content of about $500 \mathrm{~g} \mathrm{~kg}^{-1}$, was made in stead of hay because of wet harvest conditions.

\section{In situ technique}

The method of sample preparation for measuring DM degradation (DDM) with the in situ technique was as described by Dulphy et al. (1999). The procedure of the measurement was according to Michalet-Doreau et al. (1987) and the data were fitted according to the method of Ørskov and McDonald (1979). Effective degradable DM was calculated using a passage rate $(\mathrm{kp})$ of $0.06 \mathrm{~h}^{-1}$ (situ-6-DDM) and by using a more dynamic feed dependant kp rate equal to rumen degradation rate (situ-kd-DDM) (Van Vuuren, 1993). Each forage was incubated in two series for each incubation period in three cows, receiving a ration with $70 \%$ hay and $30 \%$ concentrate.

\section{Gas production technique}

The forages were incubated in quadruplicate in the gas production technique, as described by Cone et al. (1996). Gas production profiles were described with a three-phasic model (Groot et al., 1996), describing the gas production assumed to be caused by fermentation of the soluble components (phase 1), the non-soluble components (phase 2) and microbial turnover (phase 3) (Cone et al., 1997). Each phase is described by three parameters: A (maximum gas production, $\mathrm{ml} / \mathrm{g} \mathrm{OM}$ ), B (time at which $50 \%$ of the maximal gas production is reached in $\mathrm{h}$ ) and $\mathrm{C}$ (parameter determining the shape of the curve, without dimension). The gas production after 20 $\mathrm{h}$ of incubation (GP20) was used in the comparisons.

\section{Chemical analysis}

DM contents of feed and residues in nylon bags were determined after drying at $80^{\circ} \mathrm{C}$ for $48 \mathrm{~h}$ and ash content was determined after $6 \mathrm{~h}$ at $550^{\circ} \mathrm{C}$. $\mathrm{N}$ was determined using the Kjehldahl method (AOAC, 1980). Neutral detergent fibre 
(NDF) was determined in the samples dried at $60^{\circ} \mathrm{C}$ without the use of sodium sulphite and alpha amylase, using the method described by Van Soest et al. (1991), but the results were expressed with residual ash.

\section{RESULTS}

The variation in quality of the 12 forages resulted in large ranges of parameters measured with the in situ technique and the gas production technique (Table 1). GP20 was well related with situ-kd-DDM $\left(\mathrm{R}^{2}=0.53\right)$ and not related with situ6 -DDM $\left(\mathrm{R}^{2}=0.22\right)$. The relationship between $\mathrm{kd}$ and $\mathrm{B}$ from the second phase of the gas production profile $(\mathrm{B} 2)$ was moderate $\left(\mathrm{R}^{2}=0.37\right)$. This relationship was better $\left(\mathrm{R}^{2}=0.49, \mathrm{n}=75\right)$ with the forages from the database used in Gosselink et al. (2004).

Table 1. Dry matter (DM, $\left.\mathrm{g} \mathrm{kg}^{-1}\right)$ and chemical composition $\left(\mathrm{g} \mathrm{kg}^{-1} \mathrm{DM}\right)$ of the 12 forages. The soluble DM fraction (a), degradable DM fraction (b) and the degradation rate $\left(\mathrm{kd}, \mathrm{h}^{-1}\right)$ of the 12 forages measured with the in situ technique. The parameters B2, C2 and the gas production after $20 \mathrm{~h}$ of incubation (GP20) were derived from incubation of the 12 forages with the gas production technique

\begin{tabular}{|c|c|c|c|c|c|c|c|c|c|c|c|}
\hline \multirow[t]{2}{*}{ Forage } & \multirow{2}{*}{$\begin{array}{l}\text { Method of } \\
\text { conservation }\end{array}$} & \multirow[t]{2}{*}{$\mathrm{DM}$} & \multirow[t]{2}{*}{ Ash } & \multirow[t]{2}{*}{$\mathrm{CP}$} & \multirow[t]{2}{*}{ NDF } & \multicolumn{3}{|c|}{$\begin{array}{l}\text { In situ } \\
\text { technique }\end{array}$} & \multicolumn{3}{|c|}{$\begin{array}{l}\text { Gas production } \\
\text { technique }\end{array}$} \\
\hline & & & & & & A & $\mathrm{B}$ & $\mathrm{kd}$ & $\mathrm{B} 2$ & $\mathrm{C} 2$ & GP20 \\
\hline \multirow[t]{3}{*}{ Lucerne } & Fresh & 162 & 138 & 198 & 498 & 32.0 & 41.0 & 0.114 & 8.04 & 2.50 & 164 \\
\hline & Silage & 212 & 98 & 182 & 438 & 38.0 & 37.8 & 0.077 & 7.56 & 2.51 & 182 \\
\hline & Hay & 861 & 99 & 171 & 560 & 21.2 & 49.1 & 0.074 & 8.24 & 2.46 & 159 \\
\hline \multirow{3}{*}{$\begin{array}{l}\text { Red } \\
\text { clover }\end{array}$} & Fresh & 127 & 120 & 168 & 492 & 48.5 & 35.2 & 0.106 & 6.94 & 2.70 & 218 \\
\hline & Silage & 171 & 92 & 166 & 478 & 35.2 & 45.7 & 0.101 & 6.48 & 2.31 & 203 \\
\hline & Haylage & 524 & 108 & 128 & 475 & 35.4 & 46.3 & 0.059 & 6.87 & 2.40 & 209 \\
\hline \multirow{3}{*}{$\begin{array}{l}\text { Orchard } \\
\text { grass }\end{array}$} & Fresh & 193 & 80 & 116 & 676 & 22.4 & 58.4 & 0.051 & 8.77 & 2.77 & 183 \\
\hline & Silage & 217 & 71 & 126 & 614 & 26.8 & 59.3 & 0.037 & 8.39 & 2.89 & 188 \\
\hline & Hay & 852 & 70 & 110 & 697 & 16.4 & 66.5 & 0.035 & 10.0 & 2.81 & 165 \\
\hline \multirow{3}{*}{$\begin{array}{l}\text { Lolium } \\
\text { perenne }\end{array}$} & Fresh & 182 & 98 & 91 & 620 & 27.1 & 55.0 & 0.054 & 7.84 & 2.48 & 222 \\
\hline & Silage & 191 & 92 & 101 & 578 & 32.4 & 49.7 & 0.051 & 8.30 & 2.77 & 210 \\
\hline & Hay & 873 & 96 & 91 & 632 & 24.8 & 55.0 & 0.053 & 8.71 & 2.65 & 192 \\
\hline
\end{tabular}

\section{DISCUSSION}

The results showed that rates of degradation and passage in the rumen are important when comparing the gas production technique and the in situ technique. The relationship between kd from the in situ technique and B2 from the gas production technique was also observed by Cone et al. (1998) with OM 
degradation of grass. Rymer and Givens (2002) showed also that the dynamic parameters from these techniques are related.

This study showed the importance of a dynamic $\mathrm{kp}$, because effective degradable DM calculated with the in situ technique was related with the gas production when $\mathrm{kp}$ was expressed as function of $\mathrm{kd}$. The reason for this is that in roughage with a slower rate of degradation the increase in functional specific gravity will be more gradual, and thus, the slower rate of degradation is compensated by a slower kp (Van Vuuren, 1993).

\section{CONCLUSIONS}

The in situ technique and the gas production technique showed similarity in mimicking the dynamics of rumen DM degradation of forages.

\section{REFERENCES}

AOAC, 1980. Official Methods of Analysis, Association of Official Analytical Chemists. 13th Edition. Washington, DC

Cone J.W., Van Gelder A.H., Driehuis F., 1997. Description of gas production profiles with a three phasic model. Anim. Feed Sci. Tech. 66, 31-45

Cone J.W., Van Gelder A.H., Valk H., 1998. Prediction of nylon bag degradation characteristics of grass samples with the gas production technique. J. Sci. Food Agr. 77, 421-426

Cone J.W., Van Gelder A.H., Visscher G.J.W., Oudshoorn L., 1996. Influence of rumen fluid and substrate concentration on fermentation kinetics measured with a fully automated time related gas production apparatus. Anim. Feed Sci. Tech. 61, 113-128

Dulphy J.P., Demarquilly C., Baumont R., Jailler M., L'Hotelier L., Dragomir C., 1999. Study of modes of preparation of fresh and conserved forage samples for measurement of their dry matter and nitrogen degradations in the rumen. Ann. Zootech. 48, 275-288

GenStat, 2002. Reference Manual, Release 6.1. VSN International, Oxford (UK)

Gosselink J.M.J., Dulphy J.P., Poncet C., Jailler M., Tamminga S., Cone J.W., 2004. Prediction of forage digestibility in ruminants using in situ and in vitro techniques. Anim. Feed Sci. Tech. (in press)

Groot J.C.J., Cone J.W., Williams B.A., Debersaques F.M.A., Lantinga E.A., 1996. Multiphasic analysis of gas production kinetics for in vitro fermentation of ruminant feeds. Anim. Feed Sci. Tech. 64, 77-89

Michalet-Doreau B., Vérité R., Chapoutot P., 1987. Méthodologie de mesure de la dégradabilité in sacco de l'azote des aliments dans le rumen. Bull. Techn. CRZV. Theix, INRA 69, 5-7

Ørskov E.R., McDonald I., 1979. The estimation of protein degradability in the rumen from incubation measurements, weighted according the rate of passage. J. Agr. Sci. 92, 499-503

Rymer R., Givens D.I., 2002. Relationships between patterns of rumen fermentation measured in sheep and in situ degradability and the in vitro gas production profile of the diet. Anim. Feed Sci. Tech. 101, 31-44

Tamminga S., Van Straalen W.M., Subnel A.P.J., Meijer R.G.M., Steg A., Wever C.J.G., Blok M.C., 1994. The dutch protein evaluation system: the DVE/OEB-system. Livest. Prod. Sci. 40, 139-155

Van Soest P.J., Robertson J.B., Lewis B.A., 1991. Methods for dietary fiber, neutral detergent fiber, and nonstarch polysaccharides in relation to animal nutrition. J. Dairy Sci. 74, 3583-3597

Van Vuuren A.M., 1993. Digestion and nitrogen metabolism of grass fed dairy cows. Thesis. Wageningen Agricultural University, Wageningen, pp. 1-134

Vérité R., Michalet-Doreau B., Chapoutot P., Peyraud J.-L., Poncet C., 1987. Révision du système des protéines digestibles dans l'intestin (P.D.I.). Bull. Tech. CRZV. Theix, INRA 70, 19-34 